\title{
HUBUNGAN SOSIODEMOGRAFI DENGAN KEIKUTSERTAAN SKRININGPENYAKIT INFEKSI MENULAR SEKSUAL PADA WANITA PEMANDU KARAOKE
}

\author{
Cahyaningrum¹, Zahroh Shaluhiyah², Antono Suryoputro ${ }^{3}$ \\ Email: Cahya.ningrum@ymail.com. \\ 1,2,3 DIV Kebidanan Fakultas ilmu kesehatan Universitas ngudi waluyo \\ Jln. Gedongsongo Candirejo Ungaran Kab. Semarang \\ Telp/Fax (024) 6925406
}

\begin{abstract}
Abstrak
Penyakit Menular Sexual dapat diartikan sebagai penyakit-penyakit yang dapat ditimbulkan karena adanya serangan organisme yang berbentuk virus, parasit, dan kutu kelamin yang sebagian besar menular melalui hubungan seksual baik yang berlainan jenis maupun sesama jenis. Pekerja seks bekerja dalam berbagai macam bentuk. Mereka dapat bekerja di lokalisasi terdaftar di bawah pengawasan medis atau dapat juga sebagai Wanita Pekerja Seks Tidak Langsung salah satunya adalah pemandu karaoke. Untuk menanggulangi penyebaran penyakit menular Seksual, terdapat kebijakan pemantauan kesehatan dengan pemerikasaan atau skrining IMS, melalui Klinik IMS di Puskesmas dan mobile ke lokasi, tetapi jumlah kunjungnan Pemandu Karaoke untuk skrining masih sangat kurang. Penelitian ini dilakukan untuk mengetahui hubungan faktor sosiodemografi dengan keikutsertaan screening penyakit imfeksi menular seksual. Penelitian ini merupakan jenis penelitian deskriptif analitik dengan menggunakan rancangan cross sectional. Populasi dalam penelitian adalah seluruh wanita pemandu karaoke di wilayah Wisata Karaoke Sarirejo Salatiga yang berjumlah 253. Populasi sampel dengan teknik proportionate stratified random sampling.Pengumpulan data tentang sosiodemografi dan keikutsertaan screening dengan kuesioner. Data analisis dengan uji Chi Square. Hasil penelitian menunjukan faktor yang berhubungan secara signifikan terhadap praktik skrining yaitu umur, lama kerja dengan hasil $p$ value umur 0,045 , dan p-value lama kerja yaitu 0,001 .
\end{abstract}

Kata kunci : sosiodemografi, skrining penyakit menular seksual, pemandu karaoke.

\section{Pendahuluan}

Penyakit Menular Seksual atau yang sering disebut PMS atau Sexual Transmited Diseas, dapat diartikan sebagai penyakitpenyakit yang dapat ditimbulkan karena adanya serangan organisme yang berbentuk virus, parasit, dan kutu kelamin yang sebagian besar menular melalui hubungan seksual baik yang berlainan jenis maupun sesama jenis. IMS adalah infeksi yang sebagian besar menular lewat hubungan seksual dengan pasangan yang sudah tertular. Hubungan seks ini termasuk hubungan seks lewat liang senggama, lewat mulut (oral) atau lewat dubur ${ }^{[1]}$.

Masyarakat Indonesia masih berisiko tinggi menderita infeksi menular seksual (IMS), termasuk HIV/AIDS. Kurangnya pengetahuan mengenai penyakit ini, ketidaksetiaan dan ketidakjujuran pasangan, disebut-sebut sebagai pemicunya. Infeksi menular seksual masih menjadi ancaman bagi masyarakat Indonesia. Meski sudah memasuki era globalisasi yang menganut sistem keterbukaan, penduduk di Tanah Air masih kekurangan informasi dasar mengenai kesehatan reproduksi. Ada beberapa cara untuk mencegah tertular infeksi menular seksual (IMS), yaitu : jauhi seks, bersikap saling setia, cegah pakai kondom, dan datang rutin periksa ke layanan kesehatan (skrining), karena sebagian besar kasus IMS tanpa gejala (asimptomatik) ${ }^{[2]}$.

Pekerja seks bekerja dalam berbagai macam bentuk. Mereka dapat bekerja di lokalisasi terdaftar di bawah pengawasan medis (direct sex workers) atau dapat juga sebagai Wanita Pekerja Seks Tidak Langsung (indirect sex workers). Wanita Pekerja Seksual Tidak Langsung (indirect sex workers) mendapatkan klien dari jalan atau ketika bekerja di tempat-tempat hiburan seperti kelab malam, panti pijat, diskotik, café, tempat karaoke atau bar. Beberapa dari mereka adalah WPS yang sudah pernah bekerja di lokalisasi tetapi keluar dari lokalisasi kemudian bekerja menjadi WPS Tidak Langsung di tempattempat hiburan yang mereka anggap memiliki kelas yang lebih tinggi. Ada juga 
yang merasa lebih fleksibel dengan bekerja sebagai WPS Tidak Langsung karena tidak diatur ketat oleh mucikari. Bahkan ada juga karena melihat peluang untuk mendapatkan tambahan uang lebih ketika mereka bekerja sebagai pemandu karaoke, pelayan bir, atau pramuria di tempat hiburan malam. Mereka diketahui memiliki angka IMS yang lebih tinggi dibandingkan pekerja seks di lokalisasi. ${ }^{3}$

Hal ini perlu mendapat perhatian yang serius karena jumlah Wanita Pekerja Seksual Tidak Langsung (indirect sex workers) diperkirakan semakin meningkat dari tahun ke tahun. ${ }^{[3]}$

Pemandu Karaoke (PK) yang merupakan salah satu bentuk WPS tak langsung merupakan salah satu populasi berisiko tinggi terinfeksi IMS akibat seringnya berhubungan seks berganti-ganti pasangan dan perilaku pencegahan penularan IMS yang rendah, seringkali hubungan seks tersebut dilakukan secara tidak aman, seperti tidak menggunakan kondom ketika melayani klien, sehingga skrining IMS bagi pemandu karaoke menjadi penting untuk dilakukan. ${ }^{[3]}$

Layanan kesehatan IMS merupakan kegiatan pemeriksaan dan pengobatan rutin masalah IMS bagi masyarakat umum dan populasi resiko tinggi (WPS, LSL, Waria, Pelanggan). Program ini sudah dilaksanakan di Puskesmas Sidorejo Lor baik yang statis dan mobile ke kelompok resiko tinggi. Namun demikian,tidak semua wanita pemandu karaoke mau melakukan skrining IMS karena beberapa alasan. ${ }^{[4]}$

Green menganalisis perilaku manusia berangkat dari tingkat kesehatan. Bahwa kesehatan seseorang atau masyarakat dipengaruhi oleh 2 faktor pokok, yaiitu faktor perilaku (behavior causes) dan faktor luar perilaku (non behavior causes), maka dapat dilihat bahwa perilaku tidak mengikuti praktik skrininig padapemandu karaoke di banyak dipengaruhi oleh faktor luar. ${ }^{[5]}$

Beberapa hasil penelitian menyatakan bahwa pekerja seks tidak langsung (indirect sex worker) memiliki kasus IMS lebih tinggi dan memiliki perilaku pencegahan lebih rendah daripada pekerja seks di lokalisasi. Di sisi lain diketahui bahwa kurangnya program pencegahan HIV yang ditujukan untuk Wanita Pekerja Seksual Tidak Langsung (indirect sex workers) karena kesulitan menentukan kelompok ini yang disebabkan karena mobilitas dan ilegalitas dari pekerjaan tersebut ${ }^{[6]}$.

Tujuan umum dari penelitian ini adalah untuk mengetahui hubungan faktor sosiodemografi dengan keikutsertaan pemeriksaan penyakit infeksi menular seksual pada wanita pemandu karaoke.

\section{Metode Penelitian}

Jenis penelitian ini dirancang menggunakan metode kuantitatif, yaitu mengetahui hubungan fktor sosiodemografi dengan keikutsertan wanita pemandu karaoke di wilayah Wisata Karaoke Sarirejo Salatiga dalam pemeriksaan penyakit Infeksi Menular seksual diKlinik IMS Puskesmas Sidorejo Salatiga.

Populasi yang digunakan dalam penelitian adalah seluruh wanita pemandu karaoke di wilayah Wisata Karaoke Sarirejo salatiga yang berjumlah 253. Populasi sampel di tentukan dengan teknik proportionate stratified random sampling. Pengambilan sampel dilakukan di RT 01, RT 02, RT 03 lingkungan RW IX di wilayah lokasi wisata karaoke Sarirejo Salatiga. Dalam pengambilan sampel, peneliti dibantu oleh 5 orang asisten peniliti, yang sebelumya dilakukan persamaan persepsi tentang kuisioner dan mekanisme pengambilan sampel penelitian.

Variabel dependen dalam penelitian ini adalah keikutsertaan skrining penyakit IMS pada Pemandu Karaoke di wilayah wisata karaoke Sarirejo Salatiga di Klinik IMS Puskesmas Sidorejo Salatiga. Variabel independen dalam penelitian ini adalah : Sosiodemografi, meliputi: Umur, Tingkat Pendidikan, Lama Kerja.

Jenis data yang dikumpulkan dalam penelitian ini adalah data primer dan data sekunder. Teknik pengumpulan data primer dilakukan dengan menggunakan kuesioner yang telah disediakan oleh peneliti. Data sekunder dimanfaatkan sebagai data pelengkap atau pendukung data primer yang berhubungan dengan keperluan penelitian. Dalam penelitian ini data sekunder diperoleh dengan studi dokumentasi yang 
berupa pencatatan data tertulis yang berada di Dinas Kesehatan Kota Salatiga tentang jumlah Wanita Pemandu Karaoke. Alat pengumpulan data menggunakan kuisioner. Sebelum digunakan dalam wawancara dengan responden, instrumen diuji terlebih dahulu dengan melakukan uji coba pada subyek lain yang bukan merupakan populasi sasaran.

$\begin{array}{ccc}\text { Pengolahan } & \text { data } & \text { penelitian } \\ \text { menggunakan } & \text { program } & \text { Statistical }\end{array}$ Programme for Social Science (SPSS). Analisis univariat dilakukan untuk menggambarkan variabel penelitian secara deskriptif dalam bentuk distribusi frekuensi. Analisis bivariat dilakukan untuk mengetahui hubungan antar variabel penelitian. Analisis menggunakan uji statistik chi square dengan selang kepercayaan $95 \%$.

\section{Hasil dan Pembahasan}

a. Analisis Univariat

\begin{tabular}{lcccccc}
\hline & \multicolumn{2}{c}{ Umur } & \multicolumn{3}{c}{ Pendidikan } & \multicolumn{2}{c}{ Status Bekerja } \\
& Muda & Dws & Tinggi & Rendah & Lama & Baru \\
\hline Frek & 58 & 92 & 52 & 98 & 105 & 45 \\
$\%$ & 38.7 & 61.3 & 65,3 & 34,7 & 70,0 & 30,0 \\
\hline
\end{tabular}

\section{Umur}

Umur adalah penggolongan usia responden, satu tahun dihitung sejak tahun kelahiran sampai dengan pada saat dilakukan penelitian. Umur dikelompokkan pergolongan umur dengan kategori muda adalah usia kurang dari 20 tahun dan dewasa adalah pengkategorian usia lebih dari 20 tahun. Berdasarkan penelitian menunjukan hasil dari 150 responden sebagian besar berusia $>20$ tahun yaitu 92 responden $(61.3 \%)$, dan sisanya kategori umur muda 58 responden $(38,7 \%)$. Sedangkan rata - rata usia responden 24 tahun. Dengan usia termuda 18 tahun dan usia tertua 34 tahun.

Berdasarkan kelompok umur, rata-rata umur responden dalam penelitian ini adalah 24 tahun. Sebanyak 58 responden $(38,7 \%)$ masih dalam usia remaja (dibawah 20 tahun), artinya bahwa ada sebagian wanita pemandu karaoke dalam penelitian ini adalah berumur relatif muda. Pada umumnya mereka melakukan hubungan seks pertama pada usia belasan atau awal usia dua puluhan tahun dengan pasangan yang tidak resmi dan tidak diketahui tentang status kesehatan seksualnya.

\section{Tingkat Pendidikan}

Tingkat pendidkan adalah jenjang sekolah formal yang pernah diikuti responden berdasarkan ijazah terakhir yang dimiliki. Tingkat pendidikan dikelompokkan dengan kategori rendah adalah jenjang sekolah dengan pendidikan terakhir tidak tamat SD, tamat SD atau sederajat dan tamat SMP atau sederajat dan kategori tinggi adalah responden dengan pendidikan terakhir tamat SMA atau sederajat dan tamat perguruan tinggi. Berdasarkan penelitian menunjukan bahwa dari 150 responden sebagian besar responden dengan kategori pendidikan rendah yaitu 98 responden $(34,7 \%)$, dan sisanya dengan kategori pendidikan tinggi sebanyak 52 responden $(65,3 \%)$. Dari semua responden tidak ada responden yang tidak tamat SD atau sederajat.

Berdasarkan tingkat pendidikan, sebagian besar responden berpendidikan rendah atau lulus $\mathrm{SD} / \mathrm{SMP} /$ sederajat yaitu sebesar $65,3 \%$ atau sejumlah 98 dari 150 responden. Dari semua responden tdak ada yang tidak tamat SD atau sederajat, ini memungkinkan responden untuk bisa membaca dan menulis dengan baik, sehingga diharapkan untuk dapat mengikuti ketika ada penyuluhan ataupun pendidikan kesehatan yang dilakukan oleh instansi kesehatan terkait hubunganya dengan penyuluhan untuk perbaikan praktik skrining IMS pada responden.

\section{Status Lama Bekerja}

Status lama bekerja adalah rentang waktu yang telah di tempuh oleh responden dalam menjalani pekerjaan sebagai pemandu karaoke sejak pertama kali sampai dengan saat dilakukan penelitian. Status lama bekerja dikelompokakn dengan kategori lama yaitu responden yang sudah bekerja sebagai pemandu karaoke lebih dari 
satu tahun dan kategori baru yaitu responden yang bekerja sebagai pemadu karaoke kurang dari satu tahun.

Hasil penelitian diketahui bahwa dari 150 responden sebagian besar status bekerja sebagai pemandu karaoke lebih dari satu tahun atau kategori lama yaitu sebanyak 105 responden $(70,0 \%)$, dan sisanya kategori baru dengan lama bekerja kurang dari satu tahun sebanyak 45 responden $(30 \%)$. Sedangkan rata - rata lama bekerja wanita pemandu karaoke adalah 20 bulan, dengan lama kerja terpendek adalah 5 bulan dan lama kerja terpanjang 36 bulan.

Berdasarkan status lama bekerja, sebagian besar responden sudah bekerja sebagai pemandu karaoke lebih dari satu tahun yaitu sebanyak 105 responden $(70 \%)$, dengan rata - rata lama bekerja adalah 20 bulan dan masa kerja paling sedikit adalah 5 bulan pada saat dilakukan penelitian dan dengan waktu kerja terlama 38 bulan. Jika Wanita Pemandu Karaoke tidak melakukan skrining, dimungkinkan upaya mempromosikan perubahan perilaku yang mengurangi risiko penyebaran penyakit IMS tidak akan terjadi. Bahkan sebaliknya, dapat terjadi penyebaran IMS secara cepat melalui hubungan seks yang tidak aman dengan pelanggan Wanita Pemandu Karaoke terlebih dengan waktu bekerja yang lama dan pastinya semakin banyak pula klien atau pasangan seksual yang pernah melakukan hubungan seksual dengan responden.

\section{Keikutsertaan Skrining Penyakit Infeksi Menular Seksual}

Praktik mengikuti skrining adalah tindakan responden mengikuti skrining IMS dalam 3 bulan terakhir. Praktik mengikuti skrining IMS dikelompokkan dengan kategori tidak mengikuti praktik skrining apabila salah satu atau lebih jawaban responden adalah tidak dan kategori mengikuti praktik skrining apabila semua jawaban pertanyaan adalah ya.

Berdasarkan hasil penelitian diketahui bahwa dari 150 responden, sebagian besar tidak mengikuti skrining IMS yaitu 101 responden $(67,3 \%)$, sisanya mengikuti skrining IMS yaitu 49 responden $(32,7 \%)$ dan seluruhnya mengikuti skrining di klinik mobile yang datang ke lokasi.

Perilaku kesehatan individu cenderung dipengaruhi kepercayaan orang yang bersangkutan terhadap kondisi kesehatan yang diinginkan, dan kurang didasarkan pada pengetahuan yang berasal dari ilmuilmu biologi. Kenyataannya memang mendukung pernyataan ini. Terhadap kondisi kesehatan yang terganggu masingmasing individu mempunyai cara yang berbeda-beda dalam mengambil tindakan pencegahan atau penyembuhannya. Pada umumnya tindakan yang diambil berdasarkan penilaian individu atau mungkin dibantu oleh orang lain, terhadap gangguan tersebut. Penilaian semacam ini menunjukkan bahwa gangguan yang dirasakan individu menstimulir dimulainya suatu proses sosial psikologis. Proses sosial semacam ini menggambarkan berbagai tindakan yang dilakukan si penderita mengenai gangguan yang dialami, dan merupakan bagian integral dari interaksi pada umumnya ${ }^{[6] .}$

\section{b. Analisis Bivariat}

Hubungan antara karakteristik
dengan praktik mengikuti skrining IMS
pada wanita pemandu karaoke di
wilayah wisata karaoke Sarirejo Salatiga.

Tabel 1.Hasil Tabulasi Silang Umur dengan keikutsertaan skrining penyakit IMS

\begin{tabular}{|c|c|c|c|c|c|c|}
\hline \multirow[t]{3}{*}{ Umur } & \multicolumn{4}{|c|}{$\begin{array}{c}\text { Praktik Mengikuti } \\
\text { Skrining }\end{array}$} & \multicolumn{2}{|c|}{ Total } \\
\hline & \multicolumn{2}{|c|}{ Tidak } & \multicolumn{2}{|c|}{$\mathrm{Ya}$} & & \multirow[b]{2}{*}{$\%$} \\
\hline & $\mathrm{f}$ & $\%$ & f & $\%$ & f & \\
\hline $\begin{array}{l}\leq 20 \\
\text { tahun }\end{array}$ & 48 & 82,8 & 10 & 17,2 & 58 & 100,0 \\
\hline $\begin{array}{l}>20 \\
\text { tahun }\end{array}$ & 53 & 57,6 & 38 & 42,4 & 92 & 100,0 \\
\hline
\end{tabular}

p-value $=0,001 \quad \mathrm{Ho}=$ ditolak

Berdasarkan tabeldiketahui bahwa responden yang tidak mengikuti skrining lebih banyak terdapat pada responden dengan umur muda atau usia $\leq 20$ tahun $(82,8 \%)$ dibanding responden dengan usia dewasa atau $>$ usia 20 tahun (57,6\%). 
Berdasarkan hasil perhitungan Chi-Square diketahui bahwa $\mathrm{p}$-value yaitu 0,001 lebih kecil dari 0,05 (p-value < 0,05), maka Ho ditolak, artinya ada hubungan antara umur dengan praktik mengikuti skrining.

Seorang remaja putri biasanya digolongkan pada manusia yang belum dewasa, karena meskipun secara fisik menyerupai orang dewasa, akan tetapi untuk bersikap dan bertanggungjawab sebagai manusia dewasa mereka belum mampu. Ketika memasuki taraf usia tersebut, mereka mulai mengalami perkembangan dalam hal pencapaian diri, pencapaian dan perkembangan moral, perkembangan psikoseksual. ${ }^{[4]}$

Hubungan antara tingkat pendidikan dengan keikutsertaan skrining penyakit IMS

Tabel 2.Hasil Tabulasi Silang Tingkat Pendidikan keikutsertaan skrining penyakit IMS

\begin{tabular}{|c|c|c|c|c|c|c|}
\hline \multirow[t]{3}{*}{ Pendidikan } & \multicolumn{4}{|c|}{$\begin{array}{c}\text { Praktik Mengikuti } \\
\text { Skrining }\end{array}$} & \multicolumn{2}{|c|}{ Total } \\
\hline & \multicolumn{2}{|c|}{ Tidak } & \multicolumn{2}{|c|}{$\mathrm{Ya}$} & \multirow[b]{2}{*}{$\mathrm{f}$} & \multirow[b]{2}{*}{$\%$} \\
\hline & $\mathrm{f}$ & $\%$ & $\mathrm{~F}$ & $\%$ & & \\
\hline Rendah & 73 & 74,5 & 25 & 25,5 & 98 & 100,0 \\
\hline Tinggi & 28 & 53,8 & 24 & 46,2 & 52 & 100,0 \\
\hline
\end{tabular}

p-value $=0,010$

Ho=diterima

Berdasarkan tabel diketahui bahwa responden yang tidak mengikuti skrining lebih banyak terdapat pada responden dengan pendidikan rendah (74,5\%) dibanding responden dengan pendidikan tinggi (53,8\%). Berdasarkan hasil perhitungan Chi-Square diketahui bahwa pvalue yaitu 0,010 lebih besar dari 0,005 (pvalue $>0,005$ ), maka Ho diterima, artinya tidak ada hubungan antara tingkat pendidikan dengan praktik mengikuti skrining IMS.

Dalam kaitan dengan kesehatan reproduksi, pada usia remaja sangat perlu memperhatikan sistem, fungsi dan proses reproduksi yang mereka miliki. Salah satu layanan kesehatan reproduksi yang sangat dibutuhkan oleh remaja yang bekerja sebagai Wanita Pemandu karaoke adalah komunikasi, informasi dan edukasi mengenai Infeksi Menular Seksual (IMS), termasuk melakukan skrining IMS sebagai salah satu cara deteksi dini terhadap penyakit IMS, yang bertujuan untuk mencegah penularan penyakit IMS, karena pemandu karaoke merupakan salah satu kelompok resiko tinggi terhadap penularan penyakit IMS. ${ }^{1}$

Hubungan antara lama bekerja dengan keikutsertaan skrining penyakit IMS

Tabel 2.Hasil Tabulasi Silang Status Bekerja Dengan keikutsertaan skrining penyakit IMS

\begin{tabular}{ccc}
\hline Status & Praktik Menikuti & Total \\
Bekerja & Skrining &
\end{tabular}

\begin{tabular}{ccccccc} 
& \multicolumn{2}{c}{ Tidak } & \multicolumn{2}{c}{ Ya } & & \\
& $\mathrm{f}$ & $\%$ & $\mathrm{f}$ & $\%$ & $\mathrm{f}$ & $\%$ \\
\hline Lama & 8 & 71, & 2 & 21, & 105 & 100,0 \\
& 2 & 8 & 3 & 9 & & \\
& & & & & & \\
Baru & 1 & 42, & 2 & 57, & 45 & 100,0 \\
& 9 & 2 & 6 & 8 & &
\end{tabular}

p-value $0,001 \quad$ Ho=ditolak

Berdasarkan tabel diketahui bahwa responden yang tidak mengikuti skrining lebih banyak terdapat pada responden yang telah bekeja lama atau lebih 1 tahun $(71,8 \%)$ dibanding responden yang bekerja baru atau kurang dari 1 tahun $(42,2 \%)$. Berdasarkan hasil perhitungan Chi- Square diketahui bahwa p-value yaitu 0,001 lebih kecil dari 0,005 (p-value $<0,005$ ), maka Ho ditolak, artinya ada hubungan antara lama bekerja dengan praktik mengikuti skrining.

Lama kerja sebagai Pemandu Karaoke, lingkungan kerja yang kurang berkualitas, dan pasangan seks yang berganti-ganti, merupakan faktor risiko terjadinya penularan IMS pada Pemandu karaoke. Penelitian menunjukkan bahwa perilaku berisiko bukan hanya dibawah kontrol wanita pemadu karaoke itu sendiri, yang biasanya mempunyai motivasi rendah dan keterbatasan dalam melakukan pencegahan dan skrining terhadap IMS, tetapi praktik seks pemandu karaoke juga dipengaruhi oleh faktor sosial ekonomi, lingkungan kerja dan sikap pengelola tempat karaoke. 
Jika pemandu karaoke tidak melakukan skrining secara rutin, dimungkinkan upaya mempromosikan perubahan perilaku yang mengurangi risiko terinfeksi dan penyebaran penyakit IMS tidak akan terjadi. Bahkan sebaliknya, dapat terjadi penyebaran IMS secara cepat melalui hubungan seks yang tidak aman dengan pelanggan pemandu karaoke, terlebih untuk responden dengan waktu bekerja yang lama.

\section{Kesimpulan}

Sebagian besar responden tidak melakukan skrining IMS yaitu sebanyak 101 responden (74\%) dan hanya 49 responden $(32,7 \%)$ yang melakukan skrining.

Faktor yang berhubungan terhadap keikutsertaan pemeriksan infeksi menular seksual yaitu umur responden dan lama kerja sebagai pemandu karaoke.

\section{Daftar Pustaka}

[1] Mundiharno. 2009. Perilaku Seksual Beresikio Tertular PMS dan HIV/AIDS. Yogyakarta: Pusat Penelitian Kependudukan Universitas Gadjah Mada

[2] UNAIDS. 2006. HIV and Sexually Transmitted Infection Prevention Among Sex Workers in Eastern Europe and Central Asia. UNAIDS Best Practice Collection.

[3] Pemkot Kota Salatiga. 2014. Salatiga Menuju Kota Karaoke.

[4] Imron, I. 2000. Perkembangan Seksualitas Remaja. Jakarta: PKBI Pusat.
[5] Green, Lawrence W. 1991. Health Promotion Planning An Educational and Environmental Approach Myfield Publishing Company Mountain Vew Toronto-London.

[6] Gochman, David S. 1997. Handbook of Health Behavior Research; Personal and Social determinants. Plenum Press New York and London. 
